\title{
Layanan Bimbingan dan Konseling Untuk Membentuk Karakter Disiplin Siswa
}

\author{
Mohammad Fani Abdul Rosyid $^{1}$, DYP Sugiharto ${ }^{2}$ dan Mungin Eddy Wibowo ${ }^{3}$ \\ Pascasarjana UNNES \\ E-mail: Fani.abdulrosyid93@gmail.com
}

\begin{abstract}
Salah satu pendidikan karakter yang dikembangkan di Sekolah Menengah Kejuruan adalah pendidikan karakter disiplin. Disiplin menjadi salah satu prasyarat bagi pembentukan sikap, perilaku dan tata tertib kehidupan yang akan mengantar siswa sukses dalam belajar. Tujuan dalam penelitian ini untuk mengetahui serta mengekplorasi bagaimana layanan bimbingan dan konseling dalam membentuk karakter disiplin siswa di SMK negeri 1 Kandeman Batang. Penelitian ini menggunakan desain kualitatif fenomenologi. Metode pengumpulan data menggunakan teknik observasi, wawancara, dokumentasi, dengan keabsahan datanya menggunakan trianggulasi. Metode analisis data yang digunakan adalah analisis deskriptif kualitatif. Hasil analisis data menunjukan bahwa pemberian layanan informasi, layanan penguasaan konten, layanan konseling individu dan kelopok, modeling, kunjungan industri, pendekatan individu, menjalin kerjasama dengan berbagai professional, melakukan kunjungan industri terjadwal, menerapkan metode clasikal condisioning dan operant condisiong dengan menerapkan sistem reword dan panishment efektif dalam meningkatkan karakter disiplin siswa. Berdasarkan temuan peneliti maka dapat disarankan bagi konselor sekolah perlu bekerjasama dengan berbagai pihak professional yang mendukung efektifitas bimbingan dan konseling.
\end{abstract}

Keywords: Layanan Bimbingan dan Konseling, Karakter, Disiplin

Open Access

Received : 2020-30-07. Published : 2020-08-31.

This is an open access article distributed under the terms of the Creative Commons Attribution 4.0 International License

Website: http://ejournal.umpri.ac.id/index.php/fokus

\section{PENDAHULUAN}

Karakter disiplin sangatlah penting dimiliki oleh manusia agar kemudian muncul nilai-nilai karakter yang baik yang lainnya. Disiplin merupakan titik masuk bagi pendidikan karakter bagi sekolah karena jika tidak ada rasa hormat terhadap aturan, otoritas, dan hak orang lain, maka tidak ada lingkungan yang baik bagi pengajaran dan pembelajaran (Lickona, 1994). Bagi sekolah SMK, penanaman nilai karakter disiplin dapat bermanfaat ke jenjang dunia karir atau dunia kerja. Perusahaan sangat menuntut disiplin, baik disiplin dalam hal waktu ataupun disiplin dalam bekerja (Stanlay, 2014). Selain itu penelitian Jusuf (2018) mengungkapkan bahwa karakter yang disiplin membuat peserta didik dapat bersosialisasi dengan baik dan konstruktif dengan kolega dan pendidik. Sedangkan Simba dan Odwar (2016) mengungkapkan bahwa disiplin memiliki hubungan positif dengan kinerja seseorang. 
Selanjutnya di sampaikan oleh Jeffrey dan Ade (2017) disiplin selain baik untuk dunia kerja ternyata memiliki pengaruh positif dan signifikan terhadap hasil belajar siswa. Selaras dengan penelitian Aulia, dkk, (2013) yang menyatakan disiplin mempunyai pengaruh luar biasa terhadap pretasi seseorang di dunia kerja. Prestasi di dunia kerja dapat di capai dengan menjaga kesehatan dan keselamatannya menggunakan kedisiplinan yang baik (Sahlan, Bachroni, 1999). Hal itu di perkuat dengan penelitian dari Maulana (2020) yang menunjukkan, bahwa program GDS (Gerakan Disiplin Siswa) membuat prestasi akademik siswa lebih baik.

Namun demikian, masih banyak siswa yang melakukan indisipliner sekolah. Perilaku Indisipliner menjadikan siswa mengalami permasalahan prestasi akademik, kurang bertanggung jawab dalam tugas, tidak taat peraturan. Seperti yang diungkapkan Bella (2017) ketidak hadiran siswa dengan kategori alpa sebagai akibat kurang disiplin belajarnya siswa di SMK Bina Wisata Lembang yang selalu mengalami kenaikan dari tahun ke tahunnya dari tahun ajaran 2013/2014 - 20152016 dengan selisih kenaikan rata-rata 7,6\%. Selain itu pelitian Adrian (2017) menyatakan di SMK PGRI 3 Cimahi masih banyak siswa yang tidak disiplin sehingga selalu melanggar peraturan yang berlaku. Senada dengan Nicholas, John, Erick (2016) mengatakan prestasi akademik di SMK Maseno Kenya tidak menjadi sorotan lingkungan karena kedisplinan yang kurang baik.

Hasil penelitian Sutrisno dan Murni (2019) menegaskan bahwa perilaku tidak disiplin siswa ditunjukkan oleh perilaku mereka sehari-hari di sekolah, seperti membolos, datang terlambat, melalaikan tugas, catatan pelajaran tidak lengkap, tidak berseragam lengkap, malas mengikuti pelajaran, acuh tak acuh pada waktu pelajaran, merokok, tidak sopan, memengaruhi teman untuk melanggar disiplin, nongkrong di warung dekat sekolah, dan bertindak hiperaktif di kelas.

Pendidikan karakter disiplin merupakan hal penting untuk diperhatikan dalam rangka membina karakter seseorang. Berbekal nilai karakter disiplin akan mendorong tumbuhnya nilai-nilai karakter baik lainnya, seperti tanggung jawab, kejujuran, kerjasama, dan sebagainya. Curvin \& Mindler mengemukakan bahwa ada tiga dimensi disiplin, yaitu (1) disiplin untuk mencegah masalah; (2) disiplin untuk memecahkan masalah agar tidak semakin buruk; dan (3) disiplin untuk mengatasi siswa yang berperilaku di luar kontrol (Wuri. 2014).

Penanaman karakter disiplin perlu di lakukan oleh setiap stake holder. Guru sebagai pendidik harus bertanggungjawab untuk mengarahkan pada apa yang baik, bisa menjadi tauladan, sabar dan penuh pengertian (Mulyasa, 2013). Salah satu pendidik adalah guru binbingan konseling konselor. Wibowo (2017) guru bimbingan konseling atau konselor adalah profesional yang memberikan layanan konseling dalam rangka membantu individu secara optimal mengembangkan diri sesuai perkembangan serta tuntutan lingkungan. Kusuma dkk (2017) menyatakan bimbingan konseling merupakan bagian yang terintegrasi dalam pendidikan di sekolah. Sedangkan Josephine dan Katola (2013) dalam penelitianya mengungkapkan bahwa bimbingan dan konselinig dapat menanamkan disiplin siswa sekolah menengah.

Berbagai layanan bimbingan dan konseling yang mungkin dapat diberikan untuk membantu siswa yang bermasalah dalam karekter kedisiplinan yaitu: layanan orientasi, layanan informasi, layanan penguasaan konten, layanan penenmpatan dan penyaluran, layanan konselinng individual, layanan konseling kelompok, layanan konsultasi, layanan mediasi dan layanan advokasi.

Tujuan dari penelitian untuk untuk mengetahui serta mengekplorasi bagaimana layanan bimbingan dan konseling dalam membentuk karakter disiplin siswa. Selain itu untuk memperoleh deskripsi keseluruhan dalam konteksnya dan mencoba 
memperoleh pemahaman yang mendalam serta memahami makna layanan bimbingan dan konseling dalam penanaman karakter disiplin siswa.

\section{METODE}

Penelitian ini menggunakan pendekatan fenomenalogi. Fokus penelitian ini adalah penanaman karakter disiplin siswa di SMK Negeri 1 Kandeman Batang. Pengambilan subjek penelitian didasarkan pada teknik snowball. Dimana pengambilan sampel yang pada awalnya sedikit dan selanjutnya bertambah untuk melengkapi data yang dibutuhkan. Sampel awal digunakan sebagai informan kunci yang akan menunjukan informan-informan selanjutnya. Pemilihan subjek berdasarkan kriteria tertentu yang sesuai dengan masalah dan tujuan penelitian. Pengumpulan data dalam penelitian fenomenologi selalu dilakukan dengan pengamatan berperan serta. Pada penelitian ini, pengamatan dilakukan dengan berperan serta sebagai pengamat. Peneliti tidak sepenuhnya sebagai pemeran serta, tetapi melakukan fungsi pengamatan. Metode pengumpulan data menggunakan teknik observasi, wawancara, dokumentasi, dan trianggulasi. Teknik analisis data yang digunakan adalah kualitatif interpretatif. Analisis data dilakukan pada pengumpulan data berlangsung dan setelah selesai pengumpulan data dalam periode tertentu. Aktifitas dalam analisis data yaitu data reduction, data display dan conclusion drawing/verifiction.

\section{HASIL DAN PEMBAHASAN}

Dari hasil penelitian ini menunjukkan bahwa SMK Negeri 1 Kandeman sebagai salah satu SMK terbaik di Jawa tengah memiliki kualitas disiplin yang cukup baik. Hal ini terbukti dengan berbagai prestasi yang diraih SMK Negeri 1 Kandeman Batang dalam berbagai bidang yang mencapai 33 prestasi di tahun ajaran 2019 - 2020 per-tanggal 18 september 2019. Seluruh prestasi tersebut diraih dengan latihan yang membutuhkan kedisiplinan diri. Selain itu, sekolah SMK Negeri 1 Kandeman juga merupakan satu dari tiga dari sekolah rujukan dalam program pemerintah ADEM.

Kepala sekolah dan warga sekolah menciptakan iklim komitmen bersinergi untuk membangun budaya disiplin siswa, terutama di sekolah. Konselor mempunyai peran penting dalam sebuah lembaga pendidikan. Peran ini terletak pada profesionalitasnya dalam penanganan masalah. Layanan bimbingan dan konseling yang diberikan dalam penanaman karakter disiplin siswa di SMK Negeri 1 Kandeman berupa (a) layanan informasi: materi yang dapat diberikan terkait masalah faktor pelanggaran disiplin siswa di atas yaitu tips meningkatkan motivasi dan minat belajar, dan tips menjaga kesehatan. Selain itu juga dapat diberikan layanan informasi kepada orang tua siswa berupa workshop yang dilakukan pihak sekolah atas prakarsa guru pembimbing dengan pemateri guru BK itu sendiri atau mendatangkan pemateri dari profesi lain. (b) layanan konseling perorangan: layanan konseling perorangan dapat diberikan kepada siswa yang melanggar disiplin agar penanganan dan upaya guru pembimbing untuk mengarahkan siswa ke arah yang lebih baik bisa berjalan optimal. (c) layanan penguasaan konten: materi yang dapat diberikan terkait masalah faktor pelanggaran disiplin siswa di atas yaitu cara mengatur waktu belajar, cara menjaga kesehatan, cara mengatur waktu bangun tidur, cara mempersiapkan perlengkapan sekolah. (d) layanan bimbingan kelompok: materi yang dapat diberikan pada saat bimbingan kelompok dengan memberikan topik tugas terkait masalah faktor pelanggaran disiplin siswa di atas, misalnya masalah dalam mengatur waktu belajar, masalah dengan kelelahan yang dialami siswa, kurang diperhatikan orang tua, dan kurangnya kontrol dari orang tua. 
Di SMK Negeri 1 Kandeman, konselor sekolah bersama petugas STP2K dan para guru mendisiplinkan diri dan siswa untuk berperilaku disiplin. Komitmen tersebut dijalankan bersama dan disosialisasikan setiap waktu, baik itu secara langsung atau tidak langsung (menyelipkan dalam materi). Dalam penerapannya, STP2K bekerjasama dengan konselor mengkondisikan kedisiplinan siswa dari mulai masuk pintu gerbang sekolah, di dalam sekolah, hingga keluar gerbang sekolah. Jadi siswa yang masuk gerbang sekolah mesti melewati petugas khusus kedisiplinan, siswa tidak dapat masuk gerbang sekolah jika siswa tidak dalam kondisi/ keadaan disiplin.

Salah satu bentuk dukungan penerapan metode clasical condisioning adalah penerapan sistem punishment dan reward. Ini artinya, SMK Negeri 1 Kandeman juga menerapkan metode operant condisioning. Siswa dikondisikan untuk selalu menuju pada perilaku disiplin. Sistem punishment diberikan kepada siswa yang melanggar kedisiplinan. Selain meggunakan punishment yang bersifat shock therapy, konselor juga membangun punishment yang lebih bersifat konstruktif spiritualis yaitu dengan hukuman-hukuman yang mendidik dan membangun spiritualitas siswa. Punishment yang diberikan kepada pelanggar mempunyai tingkatan hukuman, yaitu: ringan, menengah dan berat. Untuk lebih jelasnya dapat dilihat pada tabel berikut:

Tabel 1. Level Punishment dan Konsekuensinya di SMK Negeri 1 Kandeman

\begin{tabular}{|c|c|c|}
\hline No & Level & Konsekuwensi \\
\hline 1 & Ringan & $\begin{array}{l}\text { dibagi menjadi menjadi dua, petama: non physical } \\
\text { punishment, yaitu pencatatan dalam buku pribadi (yang } \\
\text { dibawa siswa) dan buku kasus (dibawa BK), kemudian siswa } \\
\text { akan diarahkan kemasjid untuk pembinaan dan spiritualitas; } \\
\text { kedua, physical punishment, yaitu hukuman berupa fisik, } \\
\text { seperti push up, squat jump, membersihkan sampah yang } \\
\text { berserakan, kemudian siswa akan diarahkan ke masjid untuk } \\
\text { pembinaan kedisiplinan dan spiritualitas. }\end{array}$ \\
\hline 2 & Tengah & $\begin{array}{l}\text { pelanggar yang telah berulangkali (lebih dari } 3 \text { kali dalam } \\
\text { satu minggu) melakukan pelanggaran kedisiplinan yaitu } \\
\text { physical punishment, soft (non physical) punishment, lalu } \\
\text { diserahkan kepada konselor sekolah untuk mendapatkan } \\
\text { penanganan konseling. }\end{array}$ \\
\hline 3 & Berat & $\begin{array}{l}\text { Dilevel ini diberlakukan kepada pelanggar dengan intensitas } \\
\text { berat, yaitu sudah tiga kali menandatangani surat perjanjian } \\
\text { komitmen tidak mengulang pelanggaran namun masih } \\
\text { melanggar. Punishment ini berupa scorshising hingga drop } \\
\text { out. }\end{array}$ \\
\hline
\end{tabular}

Selain menerapkan punishment, sekolah juga menerapkan sistem reward bagi siswa berprestasi dan siswa teladan, yaitu siswa yang paling disiplin diantara siswa-siswa lain. Dalam upaya penanaman karakter disiplin siswa dan membudayakan karakter disiplin siswa, SMK Negeri 1 Kandeman menerapkan beberapa metode secara bersamaan, yaitu: pertama, pembiasaan; kedua, pemahaman; ketiga, pemodelan. Penerapan metode pembiasaan (clasical condisioning) ini cukup efektif sebagai sebuah metode modifikasi perilaku. Fungsi penerapan metode clasical condisioning ini yaitu sebagai pembentukan karakter atau modifikasi perilaku disiplin juga berfungsi sebagai pemeliharaan budaya disiplin.

SMK Negeri 1 Kandeman juga menerapkan teknik teladan (modeling) sebagai bentuk komitmen bersinergi. Untuk menjaga dan merangsang komitmen tersebut, 
kepala sekolah melakukan pemantauan dan penilaian secara konsisten kepada kinerja guru dan staf, kemudian hasil dari pemantauan dan penilaian tersebut menjadi bahan raport guru yang diberikan diakhir bulan. Metode teladan yang diterapkan di SMK Negeri 1 Kandeman adalah perilaku disiplin yang mencakup: 1. Berangkat tepat waktu, 2. Menyambut siswa yang datang dan berjabat tangan denga siswa, 3. Berpakaian dengan rapi sesuai ketentuan sekolah, 4. Berpenampilan rapi dan bersih, 5. Menjalankan ibadah sesuai keyakinan masing-masing, 6. Menjalankan seluruh peraturan yang ada di sekolah. Dalam menerapkan metode teladan ini, komitmen seluruh warga sekolah menjadi hal utama untuk mendapatkan hasil yang optimal. Seluruh guru dan staff dianjurkan untuk menegur dan menindak (dalam batas kewenangan masing-masing) serta selalu mengingatkan siswa sebagai bentuk reboisasi pemahaman dan komitmen siswa dalam berdisiplin.

Untuk mendukung penanaman pemahaman karakter disiplin siswa yang mendalam, SMK Negeri 1 Kandeman juga bekerjasama kepada berbagai intansi, alumni, dan professional untuk menjadi teladan di sekolah dalam bentuk seminar. Dalam pemeliharaan budaya disiplin, konselor bekerjasama dengan STP2K untuk memantau secara langsung melalui pembelajaran/ penanaman pemahaman terhadap siswa serta menayakan dan mengecek pelanggaran atau indisipliner siswa ke STP2K selaku pelaksanan tata tertib kesiswaan untuk melihat jumlah dan jenis pelanggaran yang telah dilakukan serta nama siswa yang membutuhkan penanganan dan bimbingan. SMK Negeri 1 Kandeman Batang menggunakan sistem kridit poin yang berarti setiap pelanggaran atau indisipliner siswa dicatat dan diakumulasikan sebagai perwujutan dari hukuman. Konselor bersama seluruh warga SMK Negeri 1 Kandeman Batang cukup berhasil dalam menanamkan karakter disiplin siswa dan membudayakan kedisiplinan. Hal ini dibuktikan dengan menurunnya kasus-kasus pelanggaran kedisiplinan siswa.

Bimbingan kelompok dan bimbingan individu menjadi kegiatan rutin terjadwal di SMK Negeri 1 Kandeman, terlebih setelah siswa mendapatkan materi bimbingan dari modeling luar sekolah. Konselor membentuk kelompok-kelompok kecil (4- 6 siswa) atau kelompok besar (bimbingan klasikal) untuk pemantapan materi sekaligus sebagai bentuk tindak lanjut kegiatan bimbingan modeling luar sekolah. Bimbingan dan konseling kelompok yang dijalankan ini terjadwal secara menyeluruh di semua kelas. Konselor menyelipkan pesan-pesan dan meteri kedisiplinan dalam setiap konseling dan bimbingan kelompok. Penerapan layanan bimbingan individu, kelompok, dan klasikal diperuntukkan sebagai langkah preventif dan penguatan penanaman pemahaman siswa, terutama untuk kedisiplinan diri. Sedangkan, layanan konseling individu dan konseling kelompok diperuntukkan bagi siswa siswi yang bermasalah. Penanaman pemahaman (insigh) ini akan membentuk sebuah konstruk berpikir dalam kesadaran berdisiplin. Konsepsi-konsepsi kognitif dalam diri siswa yang sedang mengikuti aktivitas sehari-hari yang melibatkan proses berpikir (insight) dan menggunakan logika deduktif dan induktif (reasoning) akan sejalan harmonis dengan dukungan pemahaman, motivasi, dan lingkungan yang kondusif (Sumarwoto, 2016).

Di setiap layanan pribadi, kelompok, dan klasikal bertujuan untuk membentuk sebuah konsep diri pada siswa. Konsep diri adalah salah satu faktor yang mempengaruhi pembelajaran siswa dalam disiplin sekolah. Konsep diri positif, sangat penting bagi siswa untuk mengarahkan perilaku mereka sesuai dengan disiplin yang dipelajari di sekolah (Reski, dkk, 2017). Menurut Hurlock (1999: 179) konsep diri memegang peranan penting dalam mengatur perilaku serta penyesuaian seseorang dalam hidupnya, maka dari itu konsep diri menyediakan kerangka kerja yang terus 
menerus untuk memahami masa lalu dan masa mendatang serta mengarahkan tingkah laku selanjutnya.

Rasionalisasi-rasionalisasi yang digunakan untuk membangun pemahaman siswa tentang kedisiplinan tetap menjaga retorika positif, yaitu menggunakan kata-kata positif dan menghindari kata-kata negatif. Keterampilan berkomunikasi efektif ini merupakan salah satu alat yang digunakan dalam membangun hubungan yang baik antara konselor dan konseli. Nelson \& Jones dalam Hariko (2017) menjelaskan bahwa pemakaian keterampilan konseling oleh konselor dibagi menjadi lima tujuan berbeda, yaitu: (1) Supportive listening, memberi konseli perasaan dipahami dan diafirmasi; (2) Mengelola situasi bermasalah; (3) Problem management; (4) Mengubah keterampilanketerampilan buruk konseli yang menciptakan masalah bagi konseli; dan (5) Mewujudkan perubahan falsafah hidup. Terkait dengan bahasan komunikasi, faktorfaktor yang dapat menyuburkan hubungan interpersonal, yaitu: percaya; sikap suportif; dan sikap terbuka. Konstruk perspektif konselor ideal dilakukan melalui modeling dan pendekatan-pendekatan positif, motivatif, konstruktif, eksploratif, dan edukatif. Selain meggunakan punishment yang bersifat shock therapy, konselor juga membangun punishment yang lebih bersifat konstruktif spiritualis. Yaitu dengan hukuman-hukuman yang mendidik dan membangun spiritualitas siswa. Ini juga sebagai bentuk sikap terbuka konselor kepada konseli. Hubungan antara agama dan budaya akan terbentuk secara pribadi, dimana interaksi keduanya tercermin melalui pengalaman keagamaan. Jadi, penerapan pendekatan religiusitas dalam konseling serta mewujudkan budaya disiplin yang diterapkan oleh SMK Negeri 1 Kandeman Batang sangat tepat. Pelaksanaan konseling akan lebih efektif apabila pendekatan yang dipakai menyentuh aspek rasional-logis juga aspek psikis-ruhaniah melalui nilai-nilai agama dan budaya lokal yang diyakini. Karena dengan memenuhi kedua aspek diatas (rasional-logis dan psikis- ruhaniah) akan membentuk keseimbangan diri (Huda, dkk : 2019). Religiusitas dan kerohanian menentukan keberhasilan remaja dalam penyesuaian diri dengan lingkungan dan pribadi (Japar \& Purwati, 2014).

\section{SIMPULAN}

Berdasarkan hail dan pembahasan dapat disimpulkan bahwa Di SMK Negeri 1 Kandeman, konselor berperan cukup signifikan dalam membentuk budaya berkarakter siswa. Penerapan berbagai metode dan layanan bimbingan dan konseling yang efektif dalam penanaman kedisiplinan siswa membuktikan bahwa konselor telah menjawab pertanyaan besar dari awal perencanaan program bimbingan konseling. Melalui berbagai implementasi berbagai metode, diantaranya: clasical/operant condisioning melalui reward and punihment, modelling atau teladan, dan insight (menanamkan pemahaman). Metode insight dilakukan dengan memberikan berbagai layanan-layanan dalam konseling, yaitu; bimbingan individu, konseling individu, bimbingan kelompok, konseling kelompok, dan bimbingan klasikal.

Penerapan ketiga metode ini dirasa sagat tepat dan holistik, sebab ketiganya saling mempunyai keterkaitan yang sangat erat sebagai penunjang diterapkannya pendidikan karakter bagi siswa. Siswa akan secara sadar mengimplementasikan hasil dari pendidikan karakter jika siswa mempunyai pemahaman yang baik akan pentingnya berkarakter baik (insigh). Hal ini akan diperkuat oleh contoh-contoh yang diberikan oleh orang-orang terdekatnya yang dapat dilihat dengan jelas sehingga siswa akan tertarik dan mengikuti contoh-contoh yang diberikan (modeling).

Konselor juga bekerjasama untuk menciptakan pemahaman siswa untuk berdisiplin, lingkungan yang mendukung untuk berdisiplin, dan sistem sekolah yang mendukung untuk berdisiplin. 


\section{DAFTAR PUSTAKA}

Bella. 2017. Meningkatkan Kedisiplinan Melalui Menejemen Kelas. Jurnal Menejemen Perkantoran. Ejurnal.upi.rdu/index.php/jpmanper/articel

Hariko. R. 2017. Landasan Filosfis Ketrampilan Komunikasi Konseling. Jurnal Kajian Bimbingan dan Konseling. DOI: 10.17977/um001v2i22017p041

Haryono. 2016. Pengaruh Kedisiplinan Siswa dan Motivasi Belajar Terhadap Prestasi Belajar Siswa Pada Mata Pelajaran Ekonomi. Jurnal Ilmiah Kependidikan. Vol.3, No.3 November 2016. eperints.ums.ac.id

Huda, M.M., Sunawan., \& Japar, M. (2019). Raden Ngabehi Ronggowarsito TeachingsBased REBT Counseling: A Study of Raden Ngabehi Ronggowarsito Teachings in REBT Counseling Perspective. JUBK. 8 (4). ISSN: 2252-6889/ 2502-4450.

Hurlock, E.B. 1999. Psikologi Perkembangan: Suatu Pendekatan Sepanjang Rentang Kehidupan. Alih bahasa : Istiwadayati \& Soedjarwa. Edisi Kelima. Jakarta: Erlangga

Japar. M, Purwati. 2014. Religiosity, Spirituality and Adolescents' Self-Ajustment. International Education Studies. DOI;10.5539/ies.v7n10p66

Josephine W. Gitome \& Michael T. Katola. 2013. Correlation Between Students' Discipline And Performance In The Kenya Certificate Of Secondary Education. International Journal of Education and Research. www.ijern.com

Jusuf Blegur all. 2018. Students' Disciplined Character as the Effort to Improve SelfEsteem and Academic Performance. International Journal of Academic Research in Business and Social Sciences. DOI: 10.6007/IJARBSS/v8-i4/4019

Jeffrey \& Ade. 2017. The Effects Of Achievement Motivation, Learning Discipline And Learning Facilities On Student Learning Outcomes. International Journal of Development Research, 7, (09), 15471-15478.

Kusuma. R. H, Wibowo. M. E, dan Sutarno. 2017. Pengembangan Model Konseling Kelompok Berbasis Nilai-Nilai Pesantren Untuk Meningkatkan Pengaturan Diri Santri. JUBK. https://journal.unnes.ac.id.

Lickona. 1994. Educating For Caracter. New York: Bantam Book

Maulana. V, Neliawati. 2020. Pembinaan Disiplin Siswa Pada Sekolah Menengah Kejuruan. Schoulid: Indonesian Journal of School Counseling. https://jurnal.incet.org/index/schoulid

Mulyasa, E. 2013. Standar Kompetensi dan Sertifikasi Guru. Bandung: PT. Remaja Rosda Karya: Bandung.

Reski. N, taufik. Ifdil. 2017. Konsep Diri Dan Kedisiplinan Belajar Siswa. Jurnal Education. Https://doi.org/10.29210/120182184 
Sahlan. Bachroni. 1999. Stres Kerja. Buleti Psikologi, tahun VII, No.2, Hal: 28-39.

Simba, O. N dan Odwar, J. A. 2016. Impact of Discipline on Academic Performance of Public Primary School In Muhoroni Sub-County, kenya. International Journal of Education and Prctic.

Sumarwoto, V. J. 2016. Pengaruh Kedisiplinan Penggunaan Waktu Luang Untuk Belajar Pria dengan Wanita. Counscillia: Jurnal Bimbingan dan Konseling. Scholar.google.co.id

Stanley. 2014. Discipline and Academic Performance (A Study of Selected secondary Schools in Lagos. International Journal of Academic Research in Progressive Education and Development. DOI: 10.6007/IJARPED/v3-i1/758

Sutrisno J dan Murni .S. 2019. Upaya Meningkatkan Disiplin Belajar Siswa Melalui Teknik Assertive Adaptive. Jurnal Ilmiah Mahasiswa Bimbingan Konseling. http://eskripsi.stikippgribl.ac.id

Wibowo, M. E. (2017). Profesi Konselor Dalam Kurikulum 2013 Dan Permasalahannya. Jurnal Bimbingan Dan Konseling Terapan. 1 (2). h 63-85. ISSN: 2549-4511/ 2549-9092.https://www.researchgate.net/publication/323282934

Wuri. 2014 pendidikan karekter disiplin disekolah. Jurnal ilmiah pendidikan. DOI:https//doi.org/10.21831/cp.v2i2.2168 